\begin{tabular}{|c|l|}
\hline Title & The scientific information and the teaching of journalism \\
\hline Author & Proenca, Jose Luiz \\
\hline Citation & 大阪市立大学学術情報総合センター紀要. Vol. 3, p.82-86. \\
\hline Issue Date & $2002-03$ \\
\hline ISSN & $1345-4145$ \\
\hline Type & Departmental Bulletin Paper \\
\hline Textversion & Publisher \\
\hline Publisher & 大阪市立大学学術情報総合センター \\
\hline Description & \\
\hline
\end{tabular}

Placed on：大阪市立大学学術機関リポジトリ 


\title{
The Scientific Information and the Teaching of Journalism
}

\author{
José Luiz Proença ${ }^{\dagger}$
}

\begin{abstract}
Created 34 years ago, the Academic Agency of News (Agência Universitária de Notícias), of the Communications and Arts School of the University of São Paulo (USP), comes acting like a pioneering experience in the divulging of the knowledge produced by the University for communication vehicles and influencing significantly the teaching of the journalism in Brazil. Every year, firm itself as up-to-date laboratory of journalistic practice for the students and has itself revealed an effective instrument in the scientific diffusion, acting as extension vehicle of the services of USP to the community.
\end{abstract}

Keywords: Communication, Journalism, University

\section{Introdution}

In Brazil, the journalists are obligated, for law , attend them a communication faculty, which necessarily offers to your students a laboratory of professional practice. The discussion about for efficiency of these laboratorial organs (radio stations, newspapers or TV station) in the Journalism courses and the difficulties for your implantation is as old as the courses itself, implanted in Brazil starting from 1947. Created in 1968, at school of the Communications and Arts, AUN (Academic Agency of News) had the basic purpose of offer to the students of the Journalism Course the possibility of practical training in the news making and news edition.

Starting from 1971, AUN received a significant help, when it proceeded announcing, through a covenant, the scientific information produced in Spanish by the Organization of the American State. In that time, UNESCO, organ of the ONU, it bet in a communication proposal for the development and saw in the Journalism courses the possibility to implant an operation structure of an informative agency.

Professor of Journalism

School of Communication and Arts

São Paulo University - Brasil

Visiting Researcher, Media Center, Osaka City University

(October-November 2001)
There was a performance proposal as a little alternative to the news of the great international agencies (AFP, AP, UPI, Reuter), having as larger preoccupation the science and technology produced by the countries of Latin America. It was decided, so, the edition of a printed weekly bulletin that it was sent to the newspapers, radio stations and TV stations, since the big size companies situated in the more developed axis, São Paulo-Rio de Janeiro, until the cities small publications of the Interior of Brazil. The bulletins were produced by the students and supervised by teachers and monitors of the Communications and Arts School.

It was decided, so, the edition of a printed weekly bulletin that it was sent to the newspapers, radio stations and TV stations, since the big size companies situated in the more developed axis, São Paulo-Rio de Janeiro, until the cities small publications of the Interior of Brazil. The bulletins were produced by the students and supervised by teachers and monitors of the Communications and Arts School.

In year following, school solved take over officially the activity of the informative agency and was incorporated to the curriculum of the course in the chair of Informative Journalism. With that, the jobs passed the being developed in a learning core, appending the news making and edition stages. Thus, the Agency also had condition produce the news of the University of São Paulo. AUN informed, so, not 
only the derived content originally of UNESCO but also the material produced scientific by USP, in other words, seminars, thesis, researches, courses and too much manifestations of the production of own knowledge of the University of São Paulo

Such AUN's Conformation obeyed to a verification: the deficiency of the newspapers in the subjects coverage of this sector, as well as the redundancy of used sources when of the reports enlargement published by the great press in which the central theme involved scientific pronouncements. That opened for the Agency a fertile and above all useful field of work. It characterized, thus, the space for rising of current information, news production and edition and the definition of a public to who the material had interest.

In this new period, the first step was to implant a rigorous weekly periodicity for the editions, even in the intervals of the vacation, and uninterrupted operation, indispensable attributes to the credibility of the vehicle and to the students' own professional training. That only was obtained with the infrastructure mounting for the operation of the agency (newsroom staff fixed and material resources of composition, impression, finishing and distribution).

In the next years, a series of circumstances came to affect AUN's Development, some internal, other resultant of the transformations lived by the Brazilian Journalism. With that, little by little, AUN was losing some of his fundamental characteristics - coverage amplitude, constancy among editions - and, in consequence, gradually, your editorial definition. The process culminated with the suspension of the divulging continuation possibility of the material supplied by CIMPEC in 1975.

However, at the beginning of the years 80 , the alterations in the frames of existing limitations in Brazil and in the own scope of the University of São Paulo, would again come to propitiate the retaking of more effective form of the activities of the Agency. For taking again the jobs in the formulation of the goals of AUN still indicated as information couverage basic universe USP's production. That continued to be a field in which the great press or the alternative press of then could not dedicate with efficiency for lack of structure to embrace so vast and so rich area in information. However, it was possible whether verify that the journalism in general resented of news about researches or of specialized sources that could contribute with new vision about happenings of the national or international life.

The most important mark of that new phase occurred in the contents of the bulletins. At the beginning, the emissions of the information concentrated your preoccupation in announce researches projects in process inside the University. An information flux that could be defined as "inside out". In this new phase the heartfelt opposite also passed the persecuted being: happenings of the national and international life were brought to the academic community if manifest and even propose new paths. They were the next the indicative levels of this performance modality:

a) the increasing importance checked to the academic, perceptible community from the congresses great repercussion and scientific seminars, culminated by the great expression of the annual meetings of the Brazilian Society for the Progress of the Science (SBPC).

b) lack of new community's scientific voices that the Brazilian journalism demonstrated of obscure way. The newspapers, in general, felt need to discover new sources to avoid the redundancy or exhaustion of the more well-known. important names frequently well-known in the middle academic were ignored and remained outside the information circuit.

c) the need that the Journalism student felt of boarding nearer subjects of his day by day. With the circuit of outside into, had lists larger amplitude, attracting more directly students' attention.

That new direction to the activities of the Agency allowed the establishment of an laboratorial organ 
with geared coverage more specifically for the academic area in all their significant manifestations and accomplishing service rendering paper to the newspapers, magazines, radio stations, and TV stations.

\section{Theoretical Development}

The students' work close to AUN means the existence of the "do journalistic", which comprehend, basically, the data and sources rising stages of information, composition and edition of the news. These several levels project AUN's experience for the theoretical context of the several disciplines of the course. In the technical considered disciplines, it extracts concepts about news, your formulation, fundamental structure and the expression several possibility of the informative fact. About report and research techniques in Journalism propitiates the assimilation of precise and critical information concerning about of the problem that involves the report and research tasks, essential for the matters elaboration resulted from of substance. About the specific work of the alternative informative agencies, it works information linked to the dynamics of the secondary sources, their commitments and your ideology. In the matters that subsidize the journalistic language, it gathers elements for the formulation of the text of the journalistic message, fundamental space and one of the vital arguments with which confronts for práxis journalistic.

By today's days, the Agency comes working of regular form and has been as one of the laboratorial projects more effective in the students' Journalism formation of the Communications and Arts School of the University of Săo Paulo

The bulletins continue to keep the weekly periodicity and, in terms of didactic, the Agency today is bound to a specific discipline, called Laboratory of Informative Agencies, with duration of a semester and a volume of 7 hours/class weekly. The students are located in the several units of the University and run a similar work to of reporters in the great press, in other words, they choose the subjects to are covered and take care of the final composition submitting the matter already written at two teachers, coordinating of the laboratory, which also are legal responsible by the publication. The bulletins, already with the preoccupation of introducing a final text, are distributed to 250 publication, so much of the districts great press and newspapers situated in the city of São Paulo, as for the city small publications of the Interior of the State of São Paulo, some of weekly wider, fortnightly or monthly periodicity). In the case of the great press, rarely the distributed matters are used as release and published in the totality, the newspapers preferentially use the material as list and, in the too much publications, is seized in the totality.

\section{New Proposals}

In 1996, Department of Social Communication, organ that centers the information of all São Paulo University propitiated, in a joint experience with the Informative Agency discipline, the accomplishment of a study that foresaw the join of the jobs of USP Agency of News, official organ of divulging of the University with the Academic Agency of News.

The initial plan of the joint work input both agencies foresaw the two-way performance, in other words, supplying subsidies to the vehicles and helping researchers and educational take part her as information sources in communication vehicles.

The proposed goals were the one of announce the scientific production of the University close to the information vehicles, collaborating so that the institution performed to please one of your academic purpose, in other words, the one of extension of their services to the community; supply subsidies to their educational and searching for the understanding of the important paper of the communication vehicles, as well as your operations mechanisms, journalistic practices, editorial lines, segmentation of the reader public.

Considering that for USP is a production great universe of scientific material and, consequently, of journalistic information and that gets very difficult for 
the vehicles take knowledge of all material produced by the University, the plan still introduced other suggestions. Among them, stimulate the presence of the professors and searchers in the media as much as information collaborators or information sources, providing them larger approach with vehicles and journalists, besides supplying them elements for the comprehension of the image that journalists have of the University and of your paper in teaching activities, researches and extension of the services to the community.

In terms of academic politics, the plan had as goal give larger transparency to the application of the public money; valorization of the activities of the teaching staff of the university, projection of the real image of the University, your political paper in Brazil and in the world, and the concept of your close to the national scientific jobs and international community. In the same way, the agencies could supply elements to stimulate the academic debate about actuality themes and, as opposed, collaborate so that the academic community feels motivated to manifest itself about treaties themes by the information vehicles (mostly when the theme introduce problems and for USP can collaborate in the solution). An analysis of the contacts mechanisms with the units could establish routines and procedures (thesis summaries supplied in advance, meeting lists of the advices, etc.).

The plan also stimulated the production of opinionative matters (goods and editorial) to are supplied for smaller audience newspapers (the great vehicles have more resources) like form of stimulating the beginning searchers to take part in the process of journalistic production

And it established some goals to are reached in the divulging service of USP, such as:

1 - JOURNAL BULLETIN - to be published close to the communication vehicles

2 - DIFFERENTIATED BULLETINS - to be sent for vehicles with more specialized coverage in the sciences area, in other words, newspapers, magazines, radio programs or of specific TV

3 - INTERUSP - Bulletin the being distributed exclusively for USP community.
4 - CENTRAL OF COURSES DIVULGING - The courses and events divulging inside USP was the item the section of information larger volume of the bulletins. For obvious reasons, this is one of the activities that need most the divulging services.

5 - OFFICE FOR EVENTS - For the units equiped most in the sector of journalistic divulging, USP Agency of News would have terms of placing to his disposition information distribution equipament, in other words, fax programs, direct suitcases, news emission etc.

\section{Final Considerations}

S Since that time, for USP comes gradually implanting the proposals of this plan and already can notice sensitive enlargement in the divulging process of the news, so much supplying subsidies to the vehicles as helping the professors to take part as information sources, in the measure in which it proposes to announce the scientific production of the University close to the information vehicles, collaborating so that the institution to perform more indeed your services extension academic purposes to the community.

Moreover, some of the proposed actions have been propitiating subsidies to their educational and searching for the understanding of the paper of the communication vehicles, as well as your operations mechanisms, journalistic practices, editorial lines, segmentation of the reader public, as well as to stimulate the presence of the prelecters and searching as much as information collaborators or fontes, providing an approach close to vehicles and professionals of the press.

That type of proposed also can supply for professors and searching elements for the comprehension of the image that journalist have of the University and of your paper in teaching activities, researches and extension of the services to the community.

The perspectives are wide and for final implantation of these proposed will owe if constitute in a mark, not only in the Journalism teaching, but in the future 
relations between the University and the press in Brazil. The implantation of the proposed activities already give signals of an improvement in the level of the everyday information, allied to the confidence in the role of the science and of your agents (scientists), in the environment of the composition collaborating for the social division of the scientific knowledges. This way, it will be possible to facilitate scientists' search to manifest not only about the specific themes of her knowledge areas, but enlarging their participations. The dialog among intellectual and the media is an important aspect of the contemporary democracy that has how to presuppose the information freedom and of opinion. The technical knowledge sought in the universities should be understood as able to allow the clearing and the complexity of the subjects of the actuality in areas as political, economy, arts, communications, urban violence, drugs, sports etc.

\section{References}

HERNANDO, M. C. (1982) Periodismo cientifico y sociedad. In: CONGRESSO IBEROAMERICANO DE JORNALISMO CIENTÍFICO, 4, 1982. São Paulo: Anais.

LEWENSTEIN, B. V. (1996) O que o público deve saber sobre ciência?. CONGRESSO BRASILEIRO DE JORNALISMO CIENTÍFICO, 5. 1996. Belo Horizonte: Edição especial.

MARCOVITCH, J. E (1985) e pesquisa em gestão tecnológica na América Latina. Revista de Administração. São Paulo, vol. 20, pp. 89-100.

RAMOS, Marcos Gonçalves. (1994) Modelos de comunicação e divulgação científicas - uma revisão de perspectivas. Ciências da Informação. Brasília, vol.23, no 3, pp 340-348. 